\title{
Chinese Indonesians after May 1998 How they fit in the big picture
}

\author{
DEWI ANGGRAENI
}

\begin{abstract}
For Chinese Indonesians, May 1998 is a significant historical marker, twelfth and thirteenth being two concentrated days of riots and atrocities in Jakarta, followed by more, albeit on smaller scales, in Solo, Surabaya, and a number of other cities. Destruction of properties belonging to them, and rapes of their women, occurred. Then Indonesia witnessed the end of Suharto's rule when the president resigned on 21 May 1998. A gradual political turn-around followed; Chinese Indonesians found room to move. The subsequent governments revoked restrictive regulations put in place by the New Order government, and lifted the suppression on cultural expression by Chinese Indonesians. The situation has progressed in conjunction with China's rise in global economic dominance. Does China's increasing international profile and rising global economic dominance help Chinese Indonesians? This article seeks to find some answer to the question as it looks at the development in the big picture; how and to what extent the social perceptions of Chinese Indonesians have evolved among the mainstream population; how they perceive themselves and believe how others perceive them; and how these may influence their lives as Indonesian citizens.

KEYWORDS

Chinese Indonesians; ethnic Chinese; New Order; Peranakan; May 1998; Reformasi; SKBRI; ethnic profiling; ethnic markers; media; social media; INTI; NABIL; Chinese problems; assimilation; Chinese New Year; China.
\end{abstract}

\footnotetext{
DEWI ANGGRAENI is a writer of fiction and non-fiction. She writes for Tempo, The Jakarta Post, Femina, Pesona, Jurnal Kajian Wilayah (LIPI), Wacana, Journal of the Humanities of Indonesia (Faculty of Humanities, Universitas Indonesia) in Indonesia, and other journals in Australia, Hong Kong, South Korea, and the United States. The two titles of her latest books are Breaking the stereotype; Chinese Indonesian women tell their stories (Jakarta: Indra, 2010; the Indonesian version: Mereka bilang aku China; Jalan mendaki menjadi bagian bangsa, Jakarta/Yogyakarta: Bentang Pustaka, 2010) and Tragedi Mei 1998 dan lahirnya Komnas Perempuan (Jakarta: Penerbit Buku Kompas, 2014). Her oncoming novel, My Pain, My Country, will be published in the United Kingdom in 2017. Dewi Anggraeni can be contacted at: djuta2003@yahoo.com.au.
} 
1 How Indonesia's SOCIETY EVOlVes AFter May 1998 in RELATION tO ITS ETHNic Chinese; a GlanCE AT THE BIG PICTURE

Eighteen years after the May 1998 atrocities, followed by the end of Suharto's rule, Indonesia's ethnic Chinese who live in big cities, notably in Jakarta, Bandung, and Surabaya, have increasingly come to believe that, in terms of acceptance by the mainstream society, they are in a better position. For the main part of the New Order government which ruled the country from 1966 to 1998, Chinese Indonesians were consistently singled out and placed under the spotlight, painted as the collective cause when explaining most things bad, such as being the cause of corruption, thus generating hardships to the powerless and voiceless people. Existing negative stereoty pical images were reaffirmed and endorsed, and new ones were encouraged.

Very early in its rule, in 1967, the New Order government founded a committee with a brief to examine the "Chinese problem" and find a way to resolve it (Purdey 2006: 20), sending a clear message to the public that Indonesia's ethnic Chinese indeed were causing various problems to the country and society. The government thus justified itself in issuing regulation after regulation restricting the movement of these people in order to stem the damage they have caused and are causing, as well as to prevent them from causing further mayhem. In so doing, the government sent a message to the mainstream public that it was right to be suspicious and resentful of their ethnic Chinese fellow-citizens.

May 1998 is a powerful historical marker based on two main points. Firstly, while people may have been desensitized vis-ā-vis destruction of properties belonging to Chinese Indonesians as May 1998 was not the first time this had occurred, the rapes, some horrifically perpetrated - though still officially denied up to the time this article was written - really shocked a great number of Indonesians and outraged people in a number of other countries. The second point is Suharto, who had then ruled the country for 32 years, lost power in May 1998. His fall started the unraveling of a chain of events, which are collectively known as Reformasi or social and political reform, one aspect of this reform being the gradual dismantling of the "bars" placed around Chinese Indonesians, who were then given more and more room to move.

Seen in the legal context, this gradual liberalization is very significant. Some of the landmark laws worth highlighting, passed after the demise of the New Order government are:

- Presidential Instruction of 1999, issued by the Office of President B.J. Habibie, which officially bans the use of the discriminative terms "native" and "non-native" in any official documents and transactions, and revokes the requirement for Chinese Indonesians to provide the Certificate of Proof of Indonesian Citizenship, known as the Surat Bukti Kewarganegaraan Republik Indonesia or SBKRI when seeking to obtain official documents and for other important purposes. This Presidential Instruction effectively reinforces the 1996 Presidential Instruction, which 
contains provisions that the SBKRI is no longer required by women married to Indonesian citizens, and people under eighteen years of age, whose fathers are proven Indonesian citizens,

- Presidential Instruction of 2000, issued by the Office of the next president, Abdurrahman Wahid, which removes the ban on ethnic Chinese cultural expression, the most prominent being the resumption of the Chinese New Year public celebrations,

- Presidential Decree of 2003 issued by the Office of President Megawati which declares Chinese New Year as a national holiday,

- Law No. 12 of 2006 on citizenship, issued by the Office of President Susilo Bambang Yudhoyono which provides that ethnic Chinese who are Indonesian citizens are categorized as belonging to one of the ethnic groups of the Republic of Indonesia.

In the social context, it is important to note that neither the 2000 lifting of the ban on cultural expression, nor the 2003 inclusion of the Chinese New Year in the list of national holidays, met with major opposition from the public. And most media organizations, print and electronic, generally supported the moves. Chinese Indonesians who responded to this openness were initially the relatively few who already had significant political awareness, the majority having been successfully "depolitized" for three decades.

The response was generally manifested in their greater willingness to take part in political discourse, and to a lesser degree, to participate in practical politics.

As for those who were slow to respond, being "depolitized" was only one reason, another reason being ingrained cautiousness, even distrust, of official policies, an attitude learned over decades which were often reinforced by numerous instances experienced in their day-to-day lives. ${ }^{1}$ Laws may have been passed, but practices on the ground were a completely different story. The widespread belief that it was legitimate and morally right to extort Chinese Indonesians was hard to eradicate from the community's collective psyche. A high-profile example is what Susi Susanti, an internationally-known national badminton champion, had to experience even during her days of fame. Despite being known as a prominent Indonesian sports champion, Susanti always had to produce her SKBRI whenever she needed to have official documents done. Her mother, who managed the administrative part of her life, related to her that it took eight and a half years and multiple visits, applying for her SKBRI, as each time her mother submitted the allegedly required documents for the application, she was told one or other documents were missing. And the on-going administrative costs charged were substantial. When once 
Susanti asked an official why she, an Indonesian, had to have a certificate proving her citizenship, she received an unhesitating reply, "Because you are of Chinese-descent". ${ }^{2}$

Some fields, especially the public service and politics, were effectively barred to persons of Chinese ethnicity during the New Order era. To be in these fields, they would have had to conceal their real parentage, or had been working in the said fields since a considerable time before 1966, at which point they had reached sufficient seniority and proven their mettle.

One senior public servant who transcended the New Order era, is Dora Sasongko Kartono, who began her career as a court officer at the Ministry of Justice in 1957, then promoted to the position of Judge for Jogjakarta and Magelang. In 1982, she was appointed a High Court Judge. Even so, it was only after the demise of New Order did her Chinese parentage was made public, and then it was in the context of Ms Kartono contributing to the spectrum of diverse background of women high court judges in Indonesia. ${ }^{3}$

Regardless of the slow process, ethnic Chinese have since been active in politics, economic and social commentaries, academia, creative arts, and civil service, without having to wear a different identity, regardless of their having native Indonesian sounding names or undiluted Chinese names.

Two notable examples of ethnic Chinese who have played important roles in politics are:

Kwik Kian Gie who in 1999 was appointed Coordinating Minister in President Abdurrahman Wahid's Cabinet, though he resigned his position ten months later. However between 2001-2004 he was Director of the National Development Planning Agency while simultaneously holding a ministerial position in President Megawati's cabinet; ${ }^{4}$

Mari Pangestu who was Minister of Trade from October 2004 to October 2011, who then continued to serve as Minister of Tourism and Creative Economy under President Susilo Bambang Yudhoyono until 2014. ${ }^{5}$

Generally speaking, Chinese Indonesians who have participated in politics and public life have now been largely accepted and publicly recognized, some are even lauded and have significant following. More importantly, high expectations are placed on their commitments to what they do. Detractors, especially those coming from opposing political camps, or rivals in other fields, who use the individuals' ethnicity and accompanying stereotype to beat them, are still numerous, but the efforts of these rivals no longer gain as much traction as they would have in the times before 1998.

This acceptance however, did not come without setbacks and misgivings.

3 See http://www.hukumonline.com/berita/baca/lt4d145b5284d4d/srikandisrikandi-dikursi-agung.

4 See Setyautama (2008: 154).

5 See https://en.wikipedia.org/wiki/Mari_Elka_Pangestu. 
Decades of insinuated and overtly sanctioned prejudice did not wash off smoothly. It took a long time and a great deal of introspections and selfanalyses on the part of policy-makers and those who were in a position to influence - intentionally or inadvertently - public opinion, for the situation to have reached the current stage of mutual acceptance. In many respects and indeed in many areas of the country, public opinion and even mere rumors, have been able to work locals into a frenzy, in occurrences which should be of concern to everybody. They also have played a dubious role in pushing the ethnic Chinese in those locallities into a defensive stance displaying unpleasant manners which do not invoke sympathy all around.

\section{SOME OF THE SIGNificANT MOVERS OF THE CHANGE}

\section{POLITICAL AND PUBLIC FIGURES}

When a political or a public figure does or utters something in the public sphere, intentionally or inadvertently, he or she sends a particular message to those who hear it, later read it, hear about it, read about it or hear it reported.

In this context, when in 1999 President B.J. Habibie issued an instruction banning the use of the words "native" and "non-native", he sent a message of exhortation to the public, among other things, to stop singling out Chinese Indonesians as the "other". Thus when he was quoted in August 1998, ${ }^{6}$ in relation to the government's exhortations to Chinese Indonesian businesses to return to Indonesia with their capital - barely three months after the May atrocities - saying "I cannot go and take my airplane and beg them and kiss them at their feet $[\ldots] "$. The sarcastic tone sent a relatively chilling message to Indonesian Chinese, while to the non-Chinese population the message was that he was somewhat irritated by the said Chinese.

When in 2000 President Abdurrahman Wahid removed the ban on ethnic Chinese cultural expression, he lent legitimization to the said expression as part of being Indonesian. And when he declared on 30 January $2008^{7}$ and quoted in newspapers, ${ }^{8}$ that he had a Chinese ancestor named Tan Kim Han, a Chinese ambassador to Majapahit kingdom, he went even further in including the ethnic Chinese in the fabric of the nation.

When in 2003 President Megawati declared Chinese New Year as a national holiday, she declared her acceptance of Chinese Indonesians as part of Indonesian nation and, encouraged others to do the same.

Conversely, when then Vice-President Jusuf Kalla was quoted saying, ${ }^{9}$

6 See The Straits Times 5 August 1998.

7 He was at a talkshow "Living in harmony; The Chinese Heritage in Indonesia" set up in Mal Ciputra, Jalan S. Parman, West Jakarta.

8 See http://www.merdeka.com/peristiwa/saat-gus-dur-mengaku-keturunan-tionghoatulen.html.

9 See Sinar Harapan 12 October 2004. 
This is in your interest (Chinese business people - editor), I am saying this to you. When you have many poor people, many street-side hawkers shunted left and right, who is going to be burned next year? You are. Which one do you prefer? Facing discrimination or being burned, being chased out? It's alright for you, you can easily take the money overseas when something like that happens ${ }^{\prime \prime}{ }^{10}$

he reminded the country's ethnic Chinese of what could befall them if they did not toe the line, or if they complained about any "unfair treatment", and at the same time, Jusuf Kalla conveyed a message to non-Chinese Indonesians, that violence on the Chinese Indonesians was not beyond the horizon of Indonesian politics and communal life.

\section{THE MEDIA}

May 1998, which practically heralded the end of New Order rule, is also a watershed for Indonesia's media, notably the press, which had until then been forced to perform a very skillful pas de deux with the government who imposed wide-reaching restrictions on its day-to-day operation. In the early 2000s, popular social media was still yet to make its appearance - Facebook was founded in 2004 and Twitter 2006 - so print and electronic media played a significantly influential role in shaping public opinion and perception. This became crucial and worrisome when political and public figures with respective political agenda were able to manipulate those in various media organizations.

Indarwati Aminuddin, in her research article dated and published on 4 November 2002 in Pantau, ${ }^{11}$ recounts that during the 1997 monetary crisis leading up to the May 1998 violence, many print and electronic journalists in Indonesia were invited by a government team consisting of representatives of Trade and Industry Ministry, police officers, and attorneys, to join them in raiding store-rooms owned by Chinese Indonesian businesses. Once there, the print journalists promptly made copious notes of the foodstuffs stacked, the camera crews of the invited television channels began rolling, and voilà, ready-made news scapegoating Chinese Indonesians as hoarders of foodstuffs which should have been sold in the marketplace, were spread to the public. Aminuddin continues, that there seemed little effort on the part of the journalists to investigate the real reasons for the crisis, not being entirely comfortable with explaining the significance of the plummetting of the Thai baht against the US dollar in August 1997, so with deadlines fast approaching, it would have been easier to grab what was staring them in the face (the expression is my own). The result was predictable: the intensification

10 Author's translation. The original quotation: "Ini kepentingan Anda (pengusaha Tionghoa-red), saya bilang. Kalau banyak orang miskin, banyak pengusaha kaki lima yang didorong-dorong kiri kanan, tahun depan siapa yang akan dia bakar? Anda yang akan dibakar. Suka mana? Suka didiskriminasi atau suka kau dibakarin, diburu-buru. Anda enak bawa duit keluar negeri, kalau terjadi apa-apa". See http://www.bbc.com/indonesia/ berita_indonesia/2014/06/140610_lapsus_tionghoa_satu_ atau_dua.

11 See http://www.pantau.or.id/?/=d/231. 
of resentment toward Chinese Indonesians as a whole, and Aminuddin (2002) points out, this resentment largely contributed to the May 1998 violence.

"Ethnic profiling" is a term generally used in terms of policing and criminal spotting. ${ }^{12}$ If the term could be expanded for the purpose of this article, it would become apparent that for three decades Chinese Indonesians were subjected to ethnic profiling in news items. News reporting, especially concerning despicable acts involving individuals of Chinese ethnicity as perpetrators or agents, made the said persons' ethnicity very clear by employing various ethnic markers. ${ }^{13}$ The practice even continued after the onset of Reformasi. This has been done with impunity, to the extent that some have done it, or at least claimed to have done it unconsciously, that is, with no malice. In other words, it became second nature to them.

In reporting a particular event, some of these ethnic markers were explicitly mentioned while others were implied, such as in the following example. A news item in Tempo News Magazine (Tempo, Majalah Berita Mingguan) recounts an incident in Kendari, Southeast Sulawesi, in August 2001. ${ }^{14}$ The report begins with the scene at the Mandonga Market in Kendari where a crowd of 2000 or so showed up expressing their anger, throwing stones at dozens of shops owned by Indonesian citizens of Chinese-descent. Toward the middle of the report the reader understands why this group of people became the object of public ire. It was triggered, the report says, by news of inhumane treatment committed by the wife of the owner of an automobile repair shop - both of whom were Chinese-descent - on their three household servants who were non-Chinese. So it appears that the reference to the perpetrator's Chinese ethnicity is relevant.

Two local newspapers at least, reported the event: Kendari Ekspres and Kendari Pos, where the word "Chinese" was not mentioned. The perpetrator was referred to instead, as "citizen of descent" (warga keturunan), which according to Aminuddin who is of Kendari origins, ${ }^{15}$ in Kendari means "Chinese". And Aminuddin also mentions in her article that as soon as news of the assaults spread, the locals immediately assumed that the perpetrator was Chinese-descent, deducing also from the fact that she and her husband owned an automobile repair workshop - part of local, widespread nonetheless, community's ethnic-profiling.

The news quickly evolved into an issue of "Chinese versus indigenous" conquest. Chinese Indonesians in Kendari, directly involved or not, promptly issued a public apology via the media. However residents of Raha Regency, where the three young women came from, were in no state to be appeased. The situation had turned dangerously volatile. All shops belonging to Chinesedescent people were closed. Security was visibly tightened. Threatening, protesting crowds filled the street, yelling and shouting, "Burn the Chinese!

\footnotetext{
See http:/ / legal-dictionary.thefreedictionary.com/Ethnic+profiling. See http://sociology.about.com/od/E_Index/g/Ethnic-Marker.htm.

See Aminuddin 2002: http://www.pantau.or.id/?/=d/231.

See http://www.pantau.or.id/?/=d/231.
} 
Hang the Chinese! Destroy them!" Windows of shops and houses were shattered. Seeing how the situation progressed, observes Aminuddin (2002), a group belonging to a non-governmental organization, Women Care Coalition (Koalisi Peduli Perempuan), later withdrew from the protest action. "We are worried. The protest turned into an anti-Chinese action", explained Wa Ode Deli Yusniati of the Coalition. ${ }^{16}$ "We want nothing to do with that. We are only concerned about the physical assaults perpetrated on the women by their employer" ${ }^{17}$ An astute observation, it appears, by Yusniati and and a quick action by the organization.

Before even the perpetrator was taken to court, she, and unfortunately the whole ethnic Chinese segment of the society, were already pronounced guilty, and continued to carry the epithet of "ungrateful people" as they were still regarded as not belonging to the land, regardless of the number of generations their families had lived there.

In media reporting, and in everyday conversations, it had often been assumed that Chinese Indonesian business practitioners would not hesitate to commit, even initiate, corruption, colllusion and nepotism in their dealings with officials. In reality, given the same circumstances, many non-Chinese business practitioners have been known to behave similarly.

Though slow to react, at least large media organizations began to tone down their use of ethnic markers in their reporting. The slowness may have been caused by the fact that the journalists and the editors had become genuinely persuaded that each inclusion of ethnic markers was indeed relevant to the story involved. An example in this case, is Aminuddin's interview in 2002 with Bambang Harymurti, then editor-in-chief of Tempo News Magazine. Harymurti emphazised that the publication only mentioned the ethnicity [read: Chinese ethnicity - author's addition] in its reporting if it was relevant, and that there was no undercurrent of prejudice, let alone malice, on the part of the journalists or editors. ${ }^{18}$ In fact, one of the journalists who had fielded protests from some readers for using an ethnic marker, Harymurti points out, was himself a Chinese Indonesian. This really shows how deep in the collective subconscious of the people the stereotype of Chinese Indonesians was. Many things had then been accepted as normal hence perceived, correctly or incorrectly, as without malice.

Since public sentiment, and sentiment prevailing among media practitioners, tended to feed each other, if there was going to be change, it would have to occur on both sides, roughly in a concurrent manner. It is difficult however to make quantitative assessment of public sentiment without a thorough and extensive research, which is beyond the scope of this article. On the other hand, time has shown that there have been definite attempts

\footnotetext{
16 "Kami mulai khawatir kok demonya jadi anti Cina?" keluh Wa Ode Deli Yusniati (Aminuddin 2002: http://www.pantau.or.id/?/=d/231).

17 "Padahal persoalannya kan hanya penganiayaan majikan pada pekerjanya" (Aminuddin 2002: http://www.pantau.or.id/?/=d/231).

18 See http://www.pantau.or.id/?/=d/231.
} 
on the part of the media to rectify the almost impasse situation. News items put out by at least quality media organizations began to show careful and discriminating use of ethnic markers. What is more, there have been more feature stories depicting explicitly Chinese cultural aspects and cultural events around the country, as well as more favourable reporting on Chinese Indonesians and their lives, and crucially, their contribution to nation building.

For example, when 2003 Chinese New Year (after it was declared as a national holiday) was openly and sumptuously celebrated, the celebrations were widely covered, by the country's print and electronic media. There appeared to be gesture of considerable mutual nods on the part of the media and the public respectively. And since then coverage of Chinese New Year in Indonesia has become routine and continuously more varied.

In similar veins, in 2004, Tempo News Magazine dedicated 56 (excluding the advertisement) pages of its 17 August (Indonesian Independence Day commemoration) Special Edition to stories, historical background, interviews and columns on Chinese Indonesians, with no hint of undercurrent of prejudice. This large section is presented under the general heading of "Ethnic Chinese in the era of change" (Etnis Cina di zaman yang berubah). ${ }^{19}$ This gesture undoubtedly conveys a message of acceptance of the Chinese Indonesians in Indonesian nation.

Among the articles is a brief history under the title "Assimilation not mandarinization; while free from social and political shackles, Chinesedescent Indonesians are not entirely free from problems. Progress has been made, but problems still abound" (Asimilasi bukan mandarinisasi; bebas dari pemasungan politik dan budaya, masalah keturunan Cina ternyata belum selesai. Ada kemajuan, tapi masih lebih banyak persoalan), where a relatively encompassing chronological account in a time-line format is included. There are also informative and opinionated columns variously from a social scientist, a social researcher, a political scientist, a well-known writer, an economic affairs observer, and a legal scholar and law officer. One of the columnists, Bondan Winarno (2004), in his piece titled "Ethnic Chinese are coming out of the closet" (Etnis Tionghoa keluar dari lemari) mentions how ethnic Chinese had been turning out writings in various genres in Malay - a language which would later be adopted by the young nationalists who instituted the Youth's Oath as Bahasa Indonesia - long before the young nationalists themselves who were mostly Dutch-educated, were able to function in the language. This is a very important point since writings by ethnic Chinese, while having a wide impact on early national political movement, studied and analysed comprehensively by French scholar Claudine Salmon(2010), has never been officially recognized as part of Indonesian literature.

Featured also, are a number of individuals who have categorically broken the prevailing stereotype, such as an artist, art scholar and curator, Halim H.D.; an architect who specializes in heritage architecture, Budi Lim; an architect specializing in traditional architecture, Eko Agus Prawoto; a very 
hands-on social activist, Sofyan Tan; a social and human rights advocate, Ester Indahyani Jusuf. ${ }^{20}$ None of these people have been working exclusively for Chinese Indonesian communities. They are among those of Chinese ethnicity who have defied the stereotype, and have fullheartedly joined the mainstream.

The edition also has stories depicting visual and performance arts with Chinese origins which have local elements blended in, executed and performed by Chinese and non-Chinese artists and performers, which are well received by the local populations where each of them have taken roots. This special edition is not the only time Chinese Indonesians are covered in a relatively neutral, if not particularly favourable, tone and manner. Tempo News Magazine, along with its Tempo daily, has since consistently incorporated aspects of ethnic Chinese in its writing or reportage.

Other large news organizations such as Kompas, Suara Pembaruan, Media Indonesia, and the English language The Jakarta Post, and later on, The Jakarta Globe, as well as lifestyle publications such as Femina group magazines, and later on Globe Asia, also picked up the practice of very visibly including ethnic Chinese personalities and cultural aspects in their reportage and features. Explicitly negative reporting however, has often been inevitable when Chinese Indonesian individuals, high profile or not, committed crimes, white-collar or otherwise.

It is worth noting however, that this increasing tendency to cover Chinese features and cultural events may also have been a wise commercial move by the media organizations. Not only would they have attracted ethnic Chineserun businesses to place advertisements with them, but the advertisements in general would have appealed to consumers particularly in the middle-class, a fair segment of which was indeed Chinese Indonesians. Soliciting the patronage of these people could now be done without guilt. And this was likely to have been more immediate with electronic media.

In terms of impact on public sentiment, electronic media are usually more successful and more instantaneous. Print media generally appeals to those who deliberately and actively seek out information and to an extent, mentally digesting it when they read it. To a limited extent therefore, print media helps shape and modify public opinion. In the meantime, while some people do exercise their critical minds while watching television, they also absorb a lot of images and various messages contained in them subliminally. So the process is more insidiously powerful, though not necessarily lasting in a wholesome way.

In the case of ethnic Chinese issues, electronic media therefore, has not only played a significant role in shaping public sentiment, it has also influenced public perception of what is socially acceptable and conversely, what is no longer regarded as socially graceful. Television channels began to cover Chinese cultural events to varying degrees. Prominent among electronic media organizations which have paid serious attention to the issue of ethnic Chinese is Metro TV. Founded in November 2000, it has news broadcast in 
Mandarin as well as in Indonesian and English, raising the profile of Chinese language to a level comparable to English. This was particularly significant considering that up until 1998 public use of the language, along with display of other aspects of Chinese culture, had been prohibited. Metro TV has one of the most comprehensive coverage of Chinese New Year celebrations, including those of Cap Go Meh (fifteen days after the New Year's day). It even often goes further and deeper than "show" cultural aspects. In July 2011, in one of its most popular programs, Kick Andy, presenter Andy Noya canvassed the issues of ethnic Chinese stereotyping, featuring among others, Basuki Tjahaja Purnama, known affectionately as Ahok, who would become the Governor of Jakarta, who was then the Mayor of Bangka Belitung, with Natalia Soebagio of the University of Indonesia taking part in the participatory audience discussion.

In conjunction with conventional media, online media also took off, which took a fair segment of readership off the hardcopy editions. As it caters for more or less the same readership as its print sisters, online media also has treated the ethnic Chinese issues with even-handedness.

\section{MEDIA WITH QUICK FEEDBACK}

Web-logs, popularly known as blogs, have also made their appearance. While blogs have their limitations, on topical or hot issues they have stirred up meaningful discussions, some reasonably heated. In the case of Chinese Indonesian issues, there have been from time to time blogs which draw comments and debate. For instance one particular blog, posted in $2011^{21}$ did attract many (continuing until the present day) feedbacks, forming a kind of cyber group therapy. There have also been blogs which are informative and contemplative..$^{22}$ Though blogs have limited reaches, they have contributed to the change toward social and political openness, and though limitedly, in breaking down the stereotype which shackled Chinese Indonesians in the past.

When social media began to rear its head in mid 2000s, it was at first saturated with personal stories and gossip. While this situation still continues, the exponential growth of Facebook membership (1.79 billion active users recorded in the third quarter of 2016) ${ }^{23}$ has allowed a great deal more to be posted, though it is also near-impossible to obtain the whole picture of a given situation at a given time, as we all depend on the algorithm employed by Facebook. Twitter, with 317 million monthly active users recorded in the third quarter of 2016, also played an important role in disseminating instant news and information. ${ }^{24}$

Despite the limitations mentioned above, social media has uncovered sufficient areas of the big picture to reflect some interesting phenomena.

21 See http:/ / anastasiadwirahmi.wordpress.com/2010/11/10/ada-yang-bilang-aku-china/.

22 See for example, http:/ / roedin.blogspot.com.au/2011/09/kehidupan-politik-dan-sosialbudaya.html.

${ }^{23}$ See https://www.statista.com/statistics/264810/number-of-monthly-active-facebookusers-worldwide/.

24 Https://www.statista.com/statistics/282087/number-of-monthly-active-twitter-users/. 
Interaction being one of the most attractive features of social media, it usually becomes immediately obvious if a particular issue someone posts on his or her Facebook wall or Twitter space is worth discussing, and if it is, a picture will develop disclosing what people think about it, from the feedbacks or comments. One phenomenon for instance, is how the freedom to criticize those in power has reshaped the resentment in relation to the Chinese (here, it has also become obvious that not everyone in Indonesia differentiates Chinese of the People's Republic of China, or Taiwan, from Indonesians of Chinesedescent) and their place in Indonesian society. During the New Order rule, when the people were able to see blatant corrupt behaviour in the power elite, they generally would not dare direct their anger and resentment at those in power. Instead, they aimed their ire at the ready proxy: the Chinese Indonesians who colluded with them by paying exorbitant bribes, who along with the officials receiving the bribes, benefitted from this collusion. Unfortunately the people were not very discriminating in their attacks; as a result any Chinese Indonesians were vulnerable, be they guilty of collusion or not.

Now we are seeing an interesting ground shift. While Chinese Indonesians have not really moved far from the target, the government, current president Joko Widodo rather, has moved closer to the target board. Known, justifiably or otherwise, for his closeness to China, President Widodo has been put under the spotlight in a number of news reports. Regional Legislative Council A.M. Fatwa in his comment as quoted on 29 January $2016^{25}$ in an online news service for instance, accused the president as being subservient to Chinese Indonesian property business operators. This was in relation to his office allegedly expediating the US $\$ 5.5$ billion project of Jakarta-Bandung fast-rail, which was funded by the People's Republic of China's capital. Thus Fatwa implied that Chinese Indonesians were identical to the People's Republic of China. He said (as reported)

Joko Widodo may have won the 2014 presidency, but the real power holders were the taipan [a term used for Chinese Indonesian big business operators]. ${ }^{26}$

He then continued (as quoted),

Nearly 80 percent of our economy is dominated by the taipan. I am not racist, but that is what happens. This means that every government project is coveted by those taipan. Once again, I am not racist because my second wife is Chinesedescent. ${ }^{27}$

25 It was quoted by http:/ / www.inilah.com.

26 "[...] meski Joko Widodo menang dalam Pilpres 2014, namun pemegang kekuasaan yang sebenarnya adalah para cukong alias taipan-taipan properti yang ada di Indonesia".

27 "Hampir 80 persen perekonomian kita dikuasai para taipan. Bukan saya rasis, tapi ini benar terjadi. Artinya, setiap proyek pemerintah pasti tak akan lepas dari intaian para taipan-taipan itu. Sekali lagi saya tidak rasis karena istri kedua saya keturunan Tionghoa". 
What is different now, post New Order era, is that, when that news item was posted on Facebook, it received feedback of different opinions. While some comments cheered Fatwa's accusing statements, there are those who called for a more cautious analysis of the situation. Only one, interestingly, pointed to the fact that it was Chinese state-owned enterprise which was funding the fast-rail projects, not Chinese-descent Indonesian citizens, as alluded by the legislator with a Chinese-descent second wife. He may have indeed been unaware himself of the difference between China's Chinese and Indonesia's ethnic Chinese, and may have had President Widodo as his target. Whatever his motivation, his use of the "Chinese" issue only shows how Chineseness continues to be regarded as an accepted political weapon.

While the ground shift has not been earth-trembling, it is recognizable and indicative of the ever-opening minds of the public vis-ā-vis the nation's ethnic Chinese and their heterogeneity.

In general, both Facebook and Twitter remind us that while the sentiment generated by the stereotype never leaves the collective psyche of the mainstream population, at any given time issues of Chinese Indonesians only occupy a small fraction of people's minds, barring the moments when these issues are particularly topical. As such, discourse on the place of Chinese Indonesians in the nation's fabric has not had a ground-breaking quality, albeit steadily progressing. And the notion of "acceptance" of Chinese descent fellow-citizens on the part of the indigenous majority of the population carries different meanings in different people's minds. Hoon (2012: 176-177) writes that many of his respondents confounded Chinese culture with decorative items associated with the culture, such as red lanterns and the lion dance. So they said that they enjoyed the lion dance performance but objected to Chinese people speaking Mandarin in public.

And while the stereotype transcends the different political times, it evolves, and inevitably it brings different meanings in different people's perceptions.

\section{SOCIAL ACTIVISTS}

In the frame of the dismantling of the political shackles put on Chinese Indonesians, Indonesia's social activists have played a pioneering role, though they never publicly claim this. Social activists and workers in nongovernmental organizations generally have definite foci in their work. However, when May 1998 broke out, activists and volunteers in Mitra Perempuan Women's Crisis Center, Kalyanamitra, Tim Relawan untuk Kemanusiaan (The Volunteers Group for Humanity) or TruK, Tim Relawan Kemanusiaan untuk Perempuan (The Volunteers Group for Humanity Specializing in Helping Women) or TRKP, Suara Ibu Peduli (The Voice of Women Who Care), and activist-academics at Program Studi Kajian Wanita - Program Pascasarjana Universitas Indonesia, as well as various women's groups who joined the Masyarakat Anti Kekerasan terhadap Perempuan (The Community for Fighting Violence against Women), all came out in droves to join in various endeavours to help the victims, all the while acknowledging 
the ethnicity of the rape victims. A group representing the Masyarakat Anti Kekerasan terhadap Perempuan, led by Saparinah Sadli, founding professor of Program Studi Kajian Wanita - Program Pasca Sarjana Universitas Indonesia, even went to see and convinced President B.J. Habibie who had only been in power for 53 days, to release a statement of condemning the atrocities to women perpetrated in May $1998 .^{28}$

Their concerted action, in helping the victims and obtaining official condemnation from the president, conveyed a powerful message to the public, that they regarded what had been done to (the mostly ethnic Chinese) women was extreme cruelty to fellow-citizens, thus had to be strongly and explicitly condemned and the perpetrators brought to justice. Though many in the power elite were very disturbed by this, they were unable to ignore the message. More importantly, this message has started an irreversible stream of solidarity on the part of many in the mainstream community. And this solidarity has played a solid and sustainable role in gradually encouraging inclusiveness vis-à-vis the nation's ethnic Chinese.

\section{WRITERS, ARTISTS, AND SCHOLARS}

Writers, artists, and scholars move in a different circle from those who work in the political segment of life, be they public figures, political leaders or political journalists. Creative writers and artists especially, work in the realm of people's subconscious, enhancing or disturbing their existing sense of propriety and decency, and often, their comfort zone. In this era of multimedia information technology however, writers, artists, and scholars, straddle the more contemplative work of writing - and in the case of visual and performance artists, creating -, and that of more immediate impact-making appearances on television.

Briefly after the May 1998 atrocities broke out, when conventional media was still ambivalent about the rapes on the women, a very powerful short story, Clara atawa wanita yang diperkosa, ${ }^{29}$ written by well-known author Seno Gumira Ajidarma, dated 26 June 1998, shocked readers throughout Indonesia. ${ }^{30}$ And when it was translated into English (titled Clara), ${ }^{31}$ then into Japanese, it shocked readers in other countries as well. Ajidarma, who was infuriated by the doubts publicly expressed regarding whether rapes had ever happened, wrote an extremely disturbing story about a Chinese Indonesian protagonist whom he named Clara, who was sexually assaulted during the May dark events, depicting not only the horrific crime, but also the inhumanity, hence the humiliation the victim had to face when later interrogated by a very insensitive, even voyeuristic police officer. At around the same time, several stage performances were also produced in Jakarta and other cities, depicting the trauma suffered by the women. While these may have had limitations in

See Anggraeni (2014: 176-187).

See https:/ / www.scribd.com/doc/213685571/CLARA-Atawa-Wanita-Yang-Diperkosa.

Translated by Michael Bodden, see Indonesia 68 (October 1999): 157-163. 
terms of the audience they were able to reach, they conveyed a very important message of solidarity and caring. Another group which had a limited audience in the country yet had brought awareness all the way to the other side of the globe was the visual artists who had their works exhibited in Rome later that year. These artists were over 70 years old and had never considered themselves as "activists" in any manner, yet what happened in May 1998 shocked and moved them to create images of protests, a definite departure from the paintings they had produced so far. ${ }^{32}$ Many poets were also moved to pen heartfelt and eerie poems in solidarity with the victims of the atrocities.

A shift in the whole structure of film-making was also felt following the onset of reform. During the three decades of the New Order government the place of Chinese Indonesians in the industry was almost firmly on the business side, such as financing and distribution. And when Chinese Indonesians were actually depicted in films, they were in stereotypical roles, usually as greedy business people, speaking with heavily distorted accent, and unscrupulously exploiting the indigenous Indonesians that they employed. And at the end of the film, they usually repented their evil ways and promised to succumb to the official "assimilation" program, which invariably implied shedding their Chinese attributes and their disgusting greed and lack of scruples. Films made in the 2000s have very different perspectives where Chinese Indonesians are involved. Setyadi - a researcher and a documentary film-maker (Sai and Hoon 2013: 70) observes,

[...] as public depictions of Chineseness become increasingly oriented toward Mainland Chinese cultural traditions, many ethnic Chinese youth, particularly those who grew up in peranakan families, express the inability to relate to such cultural signifiers $[\ldots]$.

Thus, not only did the young Chinese Indonesians turned their back on the old "identity politics" of the New Order, but they also began to make films themselves, where they were the subjects of the stories, expressing their own feelings and views. And it is worth noting that the films the young filmmakers produced were well received by critics and reviewers, though not particularly a commercial success. Eric Sasono, ${ }^{33}$ a well-known film-critic, wrote well of them, and more importantly, included them in the repertoire of the genre of post-reform films.

A number of scholarly works and photographic essays began to appear on the subject of Chinese Indonesians, some on the history of particular regions, among them Hendri Gunawan's book on Manado's ethnic Chinese local history Yok Tjae \& Chung Hwa; Menelusuri jejak-jejak komunitas Tionghoa di Manado (2013); Erniwati's Asap Hio di Ranah Minang; Komunitas Tionghoa di Sumatera Barat (2007); and Frino Bariarcianur's photographic essay Demi waktu; Potret Tionghoa Singkawang (2005). While most books enlighten readers

33 See http:/ /9808films.wordpress.com/media-archive/. 
of the Chinese Indonesians' place and part in the national history, one book particularly worth noting is Manifesto politik Tionghoa di Indonesia by Choirul Mahfud (2013), for its implicit inclusiveness of ethnic Chinese as part of Indonesia's multicultural society, which is consistently implied throughout the book.

\section{PROACTIVE NON-PROFIT, ACTION-ORIENTED SOCIAL ORGANIZATIONS}

Various organizations, large and small, emerged after May 1998, of which the mission was more or less to work toward integration or reintegration of ethnic Chinese into the nation's mainstream society. Two prominent ones have been:

- Perhimpunan INTI or Association of INTI ${ }^{34}$ (which stands for IndonesiaTionghoa), founded in 1999 with the mission to resolve the "Chinese problem" - legacy of the New Order rule. The organization runs seminars on various topics related to the mission, as well as disbourses scholarships to indigenous young people deemed deserving. It also has published a number of books.

- Yayasan NABIL or NABIL Foundation, ${ }^{35}$ founded by a former general president of INTI, Eddie Lembong, and his wife Melly Saliman in 2005. NABIL stands for Nation Building. True to its name, NABIL focuses its work on mainstreaming the ethnic Chinese community. The regular seminars the organization runs are more multilateral and interactive in nature, such as endeavours involving non-ethnic Chinese groups, for example Paramadina University, and the Nahdlatul Ulama community organization, in working together on knowledge-sharing and community-building. It also has a prolific publishing department as well as an extensive quality library accessible to those who have legitimate needs to use it.

3 The Rise of the People's Republic of China in the global economy and SOME EFFECTS ON THE CHINESE INDONESIAN SITUATION

While the turn of the century saw increasing cultural breathing space for Indonesia's ethnic Chinese, it also saw China's growing power in the global economy. In fact, in 1999, with its 1.25 billion people but a GDP of just US $\$ 3,800$ per capita, China became the second largest economy in the world after the US ${ }^{36}$ This naturally raised concern particularly in the United States, which felt the danger of its own dominance in the global power declining. Inevitably while China's economy continued to grow, so did its bargaining and political power, and in Indonesia and many countries in the region, its spread of capital.

This economic dominance has not been lost on those who are globally

34 See http:/ / www.inti.or.id.

35 See http://www.nabilfoundation.org.

36 See http://www.fas.org/sgp/crs/row/RL33534.pdf. 
aware, be they ethnic Chinese, indigenous or descendants of other ethnicities originating in other countries. And the increasing numbers of people wanting to learn Mandarin indicates that there was a growing awareness that this dominance indeed offered a wide range of opportunities for Indonesia. For example, the Islamic Village Secondary College in Jakarta even included it in its curriculum. Anggraeni (2010: 128-129) writes,

The students at the Islamic Village Secondary College believe that Chinese is becoming a very important language in this region. Even in seeking employment, they have discovered, being able to speak and write Mandarin would place them ahead of others who had no knowledge of Mandarin [...].

On the other hand, it has also been apparent that apart from the relative few who made it their business to know the difference between China as a nation and Indonesia's own ethnic Chinese, most people are generally unaware of this difference. The former consist of academics and scholars whose fields of study are in or related to, multiculturalism, international relations and economics; business consultants, banking experts, people generally interested in social and political issues, and those who had Chinese-descent personal friends. The latter are those whose lives hardly have anything to do with ethnic Chinese, except on the occasional encounter or small transaction. To them, people of Chinese ethnicity be they citizens of Indonesia or of China or other countries, all belong to the same "pool": foreign. While this unawareness may not have normally fuelled resentment toward the ethnic Chinese in their lives, it could easily turn that way, either inadvertently or by design on the part of some party or parties with vested interest.

Reading quality newspapers and more specialist business publications, it is apparent that there are at least nine ethnic Chinese and five nonChinese Indonesian millionaires with their respective cross-border capitals whose business activities have been worth covering. However, some news organizations have often alluded to economic domination by the taipan, namely ethnic Chinese business owners. Interesting to note that, according to a study by Richard Carney and Natasha Hamilton-Hart, ${ }^{37}$ in the last two years of the New Order era, the millionaires (Chinese and non-Chinese) have gradually delisted their companies from the Indonesian Stock Exchange, and continued operating them as private companies. Siadari ${ }^{38}$ observes that this phenomenon reflected the decline of the influence of political connection in maintaining business stability as it had been in Suharto era.

However, the notion of Chinese Indonesian businesses influencing government policy appears to be maintained by some party or parties in order to be used when needed. One example is how the current president Joko Widodo's good relationship with China is depicted by some political and other

37 See http://asiapacific.anu.edu.au/blogs/indonesiaproject/files/2015/12/CarneyHamilton-Hart-What-do-Changes-in-Corporate-Ownership-in-Indonesia-Tell-Us.pdf.

38 See http://bisnis.news.viva.co.id/news/read/193883-9-taipan--sepuh--terkaya-diindonesia. 
public figures, then quoted by a number of media outlets, as the government being influenced by the taipan, having blurred the separating line between Indonesians of Chinese-descent and China's population - those in China as well as those visiting Indonesia. An example of this is an article on 23 October 2014,39 with the headline "Let's hope Jokowi is not vulnerable to 'steering' by Chinese taipan" (Semoga Jokowi tak mudah "disetir" taipan China), quoting some public figures naming ethnic Chinese business owners, when reporting on the new president being congratulated by Yan Jungqi, Vice Chairman of People's Republic of China's Congress on 21 October. An attempt to blur the difference between Indonesia's own ethnic Chinese and the People's Republic of China is apparent here.

However increasingly, in big cities where people are better informed, this type of deliberately designed image is harder to stick or to use for inciting the masses. In places where accessibility to less tendentious or biased information is not reliable though, this may not be beyond likelihood.

What has actually been happening is the increasingly closer economic ties between Indonesia and China through China-ASEAN Investment Cooperation Fund (CAF) or direct investments. And parallel with that, the agreements within Asean Economic Community and ASEAN-China Free Trade Agreements allow free exchange of technology and skilled workers between the participating countries. A result of these agreements is, Indonesia is seeing workers from China entering the country.

Unfortunately there is a drawback, unintended it may be. The sheer number of these workers coming, has tested the social and - since they are Chinese - political sensibility of local workers, who understandably feel their job security threatened. The situation was aggravated by reports that many of those workers were not even skilled, as per the terms in the agreements as well as the Minister of Manpower and Immigration's Instruction No. 247/2011 where it is specified that the only foreign workers who are allowed to work in Indonesia are those with and necessary skills. Investigations by Tempo News Magazine ${ }^{40}$ revealed that the irregularities were in the procurement of licenses by officials in the Ministry of Manpower and Immigration. However, to the local workers who feel sidelined by Chinese workers, the resentment tended to remain with the Chinese in general, ethnic Chinese included.

General unawareness of the difference between China's Chinese and Indonesian Chinese may play into the hands of party or parties which tend to take advantage of ethnicity.

\section{Perceptions and Stereotype Still PREVAiLing today}

\section{ChInESE IndONESIANS PERCEIVED By NON-CHINESE INDONESIANS}

It is safe to assume that there is a broad continuum of perceptions. On one end are perceptions held by people who have had frequent contact with

39 See www.hidayatullah.com 23 October 2014 edition.

40 See Tempo, Majalah Berita Mingguan 31 August 2015, Laporan Utama (Main Items), “Banjir pekerja dari negeri Panda" (Workers from the land of Panda flooding in). 
Chinese Indonesians, and on the other by people who have almost or entirely no contact with Chinese Indonesians, whose perceptions are based on the prevailing stereotype in their communities or anecdotal stories going around. Spread out between them are those with various degrees of combination of both. The closer it is to the first end, the denser the personal contents in the perceptions, the closer it is to the other end, the less personal the perceptions are likely to be, and the more likely the people to be less emotional and maybe more objective.

In 2004, for its Independence Day Special Edition, Tempo News Magazine interviewed a number of non-Chinese Indonesians regarding their views and perceptions about their ethnic Chinese counterparts. The people interviewed were those deemed as informed and fair. The editors selected five interviews ${ }^{41}$ to be published as they were regarded as representative of the total pool of respondents.

They are all voicing rational and sober views about the ethnic Chinese and the current situation in relation to them. They all agree that some ethnic Chinese tend to be exclusive and need to socialize more with their non-Chinese counterparts. And each respondent has certain aspect(s) they emphasize. M.S. Hidayat, (then) General President of the Indonesian Chamber of Commerce and Industry, expresses his observation that the ethnic Chinese are not monolithic; they do not express one voice in unison. He also tells of knowing ethnic Chinese individuals who are very nationalistic, who even express regrets that some of their counterparts who fled overseas after May 1998 have not returned.

Hidayat also remarked that May 1998 has taught an important lesson to Chinese-descent Indonesians, inas much as the need for introspection and behaviour modification. Dea Ananda, an artist, says that as far as the arts scene is concerned, ethnic Chinese or non-Chinese share the same room to move. However she observes that there are ethnic Chinese who tend to remain in their own cliques, and show no inclination to mix with native Indonesians. She suggests the ethnic Chinese, living in the nation's pluralistic society, make an effort to understand the cultures of other ethnic communities in order to be part of the whole society. Eros Djarot, artist and politician, says that the only definite change he has seen is the freedom of expression ethnic Chinese have enjoyed in the last few years. But he has not seen real integration happening. He points to the practice of monopoly on the part of the ethnic Chinese businesses still continuing. He also observes that while many of the ethnic Chinese business people complain of discriminative treatment against them, they themselves are unfair to their own indigenous employees. He concedes however, that the government has tended to use the ethnic Chinese for political and monetary purposes, and suggests that that practice should be discontinued because it generates resentment toward them. Jusuf Kalla, businessman and (then) VicePresident candidate says that the discrimination issues against ethnic Chinese

41 See Tempo, Majalah Berita Mingguan 17 August 2004 (special edition), “Orang Cina di mata mereka" (How they perceive the Chinese). 
are dissolving, that they are now free to any cultural expression of their own. But he exhorts them to contribute to a clean business atmophere. And successful ethnic Chinese business owners, he says, should help and support the small business owners, be they indigenous or fellow ethnic Chinese. Indra J. Piliang, researcher at CSIS (Centre for Strategic and International Studies) remarks that he is seeing improvement in the government's treatment on, and attitude toward ethnic Chinese. He states as examples the spectacular celebrations of Chinese New Year and the excellent lion dance performances throughout the country, and the acceptance of Confucian as an official religion. He points out however, that the improvement has not quite penetrated the government institutions, citing the continuing requirement for the Certificate of Proof of Indonesian Citizenship (SBKRI) as a landmark example.

Hoon's (2012: 179-190) interviews - conducted by his indigenous research assistant, presumably to create a situation more conducive for them to open up - reveal more indications of insecurity on the part of the indigenous respondents vis-ā-vis their Chinese-descent friends, colleagues, neighbours or acquaintance. However, this does not render their observations less valid, and they are just as worth listening to and pondering by those observed. The interviews were conducted in the latter part of the same year as those of Tempo's, 2004. The respondents were of a younger, but of similar social demography to those of Tempo's. In the interviews they note the positive as well as negative aspects of the Chinese-descent people they know, befriend or work for.

Of the positive traits they name, the pertinent and prominent ones are the work ethics, the clear visions, the determination, the reliable network to which they belong, the high discipline, the ability to focus, the attention to detail, the rationality and the resilience of the ethnic Chinese. However, positive as they sound, these traits could lose their shine when they were held against the respondents' own insecurity, very likely from hearing comments passed by the ethnic Chinese individuals they overheard. In fact, an observation expressed by several respondents is that they believe that ethnic Chinese see them as lazy and lacking in work ethics (Hoon 2012: 181-185). This would most likely make them feel reluctant to make friends with Chinese Indonesians. Only people possessing a solid self-esteem would voluntarily include individuals who had such low opinions about them, in their circles of friends.

The clearly negative traits the respondents name are exclusivity (a very persistent perception), excessively hard-working (to the extent of making other people feel inadequate), feeling of superiority, having no sense of connectedness with their surrounding communities, and reluctance to help those less well-off than they are.

One relatively common belief among non-Chinese Indonesians about ethnic Chinese, which is not necessarily positive or negative, is that they are all rich. This belief can cause problems or at least awkwardness in various situations. Ester Indahyani Jusuf in her work as a founder of, and volunteer 
with Solidaritas Nusa Bangsa, ${ }^{42}$ often has had to step aside and let her indigenous colleagues to go and visit community groups they seek to help, because generally as soon as they see a Chinese face (Ester's), they assume they can ask for anything as the "donor" is infinitely rich.

\section{CHINESE INDONESIANS' SELF-PERCEPTIONS VIS-Ā-VIS THE REST OF THE POPULATION}

Taking into consideration the heterogeneity of Indonesia's ethnic Chinese, for the purpose of this article I will roughly divide them into the following categories (with a note that these are not discrete groups; there is ample blurring and overlapping):

- The young adults to early fifties and mostly tertiary educated, who generally feel optimistic about the future. These people regard themselves as Indonesian, Chinese-descent, cosmopolitan all at once. They socialize with peers of different backgrounds, and are not easily non-plussed at hearing unflattering stereotype about themselves, because they are aware that other groups also have stereotypes attributed to them. Metro TV's Xinwen Chinese-language program presenter Candy Natazia Jorian, is one example. Of her sense of identity, she said in $2008 .^{43}$

Personally, I think of myself as an Indonesian. Sure, I have a Chinese name and am of Chinese descent, but I don't consider myself a Chinese citizen or anything of the kind. I'm Indonesian. It says so on my ID card, and on my passport. And anywhere I go, whoever I meet, I always declare myself as first and foremost an Indonesian citizen.

- The ones who have had frequent difficulties in relation to their ethnicity. These people are unable to be sure of their own place in Indonesian nation and society. At the same time they are aware that they do not necessarily belong to China either. This sense of displacement or living in limbo renders their lives unpleasant, and their suspicions of the world around them in turn make them appear aloof. An example is a respondent of Dawis (2009: 120-121). Dawis named this respondent Yuny, who recounted feeling fear and discomfort as a child whenever she wandered outside her house. She knew she stood out. She had fairer skin than many of the indigenous children who lived in the neighbourhood, and often had to field yells of "amoy" 44 from those around her. Her parents thus tried to protect her by having a servant accompany her each time she went outside. This only alienated her further.

42 See Anggraeni (2010: 29).

43 See The Jakarta Post, Weekender (February 2008): 20.

44 Amoy (meaning: young woman) is used to describe a Chinese or Chinese-looking young woman, and often used to call out to young women in a derogatory tone, causing the target(s) to feel uncomfortable, humiliated, even physically threatened. 
- The ones who have had difficulties in relation to their ethnicity, and believe that they are never accepted in Indonesia, so always look to China for moral support. These people continuously look for signs that China is becoming strong and dominant in the world because it makes them feel that even notionally, there is somewhere for them to go if it becomes impossible for them to continue living where they are. ${ }^{45}$

- Those who have been personally impacted by the violence generated by PP10 ${ }^{46}$ and/or by the atrocities of May 1998, yet not necessarily trusting of China coming to rescue them either. Those who can afford it, take what may appear to be drastic steps. For example, Lin Che Wei, Director of The Independent Research and Advisory, recounted to Tempo News Magazine in $2004^{47}$ why he decided to be a "weekend daddy". When May 1998 broke out, he was working for Société Générale Securities Services. On 12 May shots were fired at students gathered at Trisakti University campus. On 13 May burning, looting and general destruction were perpetrated on business and residential areas in Jakarta, and later on it was revealed, horrific rapes as well. At hearing the news Che Wei left his office. His house was not very far from that of Liem Sioe Liong, a major target. When he arrived in the area he saw Liem's house already decimated. Luckily his wife and two children had earlier on evacuated to temporary safety. Toward the end of the day, when the mayhem had begun to subside, he took a motorcycle and rode in front of his family car taking them to a hotel in Jalan Thamrin to stay. Two days after that he took his still distraught family to Singapore to live for an indefinite length of time. And he would commute to Jakarta for his working days and return to Singapore for the weekends.

- The ones across age-brackets who have to varying degrees had difficulties in relation to their ethnicity, but nonetheless are determined to be philosophical and remain mentally and morally Indonesian, living and working in Indonesia, while not denying their Chinese heritage. ${ }^{48}$

45 Recounted to the author in informal conversations and correspondence with Chinese Indonesians from 1998-2015.

46 PP 10 was a law passed by the government in November 1959, which prohibited foreign nationals from doing retail business in rural areas and required them to transfer their businesses to Indonesian nationals by 1 January 1960. Unfortunately during its implementation properties belonging to ethnic Chinese, who at the time were still unclear of where they stood in relation to their citizenships, were destroyed, and a number of Chinese were killed. This drove significant numbers of Chinese Indonesians to flee to China.

47 See Tempo, Majalah Berita Mingguan 17 August 2004 (special edition), "Bertemu ayah di akhir pekan" (Seeing dad at weekends).

48 Information recounted to the author's during informal conversations and correspondence with Chinese Indonesians from 1998-2015. 
It is not easy to determine the actual size of each category mentioned above, because they are likely to swell and contract depending on the political and social atmosphere of the moment. If I were to speculate however, I would say that the first and the last have been increasing in size in the last decade. ${ }^{49}$ This has lately been much abetted by prominence of the current Governor of Jakarta, Basuki Tjahaja Purnama, known popularly as Ahok, who has been able to break the existing stereotype to pieces as far as he is concerned, as regardless of his political leanings or modus operandi, he has proven to be consistently nationalistic, politically courageous, taking social justice seriously, and most importantly, uncorrupt. While he has a sizeable body of detractors, his acceptance by the mainstream population has been manifest. He has never denied or concealed his Chinese heritage. In fact, he is happy with people calling him Koh (Hokkien for older brother) or Pak Ahok. If Basuki Tjahaja Purnama can be globally held up as an example, it may prove that it is not necessarily the Chineseness most people dislike in Chinese Indonesians, but all the negative attributes carried by the stereotype, be they based on reality or not. Nonetheless, recent events have indicated that while the negative attributes of the stereotype are not necessarily all true or a hundred percent accurate, they can still be called upon for political purposes by parties aggrieved by certain political or economical developments. ${ }^{50}$

We have learned that there has been a concerted effort on the part of the authorities as well as the community, to open up to Chinese Indonesians and include them and their cultural heritage in the national culture in general. This has generally been welcome by the Chinese communities themselves.

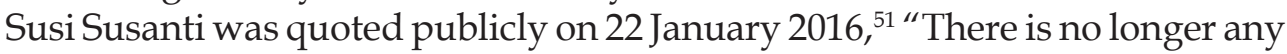
discrimination. We have progressed. Things are now more open and better".

\section{CONCLUSION}

Over sixteen years have passed since the May 1998 atrocities and the onset of Reformasi. Reformasi itself has, among other benefits, given Indonesia's

49 Information recounted to the author's during informal conversations and correspondence with Chinese Indonesians from 1998-2015.

50 On 27 September 2016, Purnama in a meeting with the local community in Pulau Seribu (in the Bay of Jakarta in the Java Sea), exhorted the community not to be swayed by certain religious figures quoting the Al Maidah 15 in the Quran to stop them from reelecting him in the February 2017 regional election. This was later used by a number of religious personalities and groups, a prominent one being the Indonesian Ulema Council, to take Purnama to court for blasphemy against Islam. A mass rally followed on 4 November in Jakarta, in support of imposing the blasphemy charge. A larger albeit more complex one then took place on 2 December 2016, also in Jakarta. While not all the religious figures named Purnama's Chineseness as an important aspect, most personalities interviewed on television channels and who wrote in social media, named it as a prominent factor for not electing Purnama the second time. Another important angle to this issue is, Purnama's Chinese ethnicity has been highlighted to support the hypothesis expressed by a number of public figures that Purnama is the beginning of Indonesia being "swallowed" by China, whose economic dominance is spreading exponentially.

51 See http://sport.merahputih.com/raket/2016/01/22/susi-susanti-diskriminasi-itusekarang-sudah-tidak-ada/37694/. 
ethnic Chinese increasing room to move. While mutual suspicions and distrust remain between ethnic Chinese and the rest of the population, the nation has come a long way since the times when the ethnic Chinese were held up as a national problem as choreographed by the New Order government. Both Chinese Indonesians and the indigenous majority of Indonesia's population have undergone a great deal of soul-searching, though a lot more of it is still necessary, if a better society is to be achieved. The rise of the People's Republic of China in global economic dominance has had an impact which, when manipulated for political purposes by certain parties, can have a negative effect on the lives of Chinese Indonesians.

An abundance of good faith however, has been shown toward the ethnic Chinese by many sectors of Indonesian society most of which are not ethnic Chinese. And this good faith does not only come from groups that benefit from ethnic Chinese's role in the economic sector. A great deal also comes from those who seek fairness for all in Indonesia. And a broad appreciative response has been shown by the ethnic Chinese for their eventual inclusion in the national life and program, though a significant degree of cautiousness and insecurity, even ingrained suspicion, still lingers all round.

\section{REFERENCES}

Ajidarma, Seno Gumira. 1998. Clara atawa wanita yang diperkosa [https:/ / www. scribd.com/doc/213685571/CLARA-Atawa-Wanita-Yang-Diperkosa; The English translation by Michael Bodden, titled Clara, see Indonesia 68 (October 1999): 157-163].

Aminuddin, Indarwati. 2002. "Prasangka media terhadap etnik Tionghoa", Pantau [http:/ / www.pantau.or.id/?/=d/231].

Anggraeni, Dewi. 2010. Breaking the stereotype; Chinese Indonesian women tell their stories. Melbourne: Indra.

Anggraeni, Dewi. 2014. Tragedi Mei 1998 dan lahirnya Komnas Perempuan. Jakarta: Penerbit Buku Kompas.

Bariarcianur, Frino. 2005. Demi waktu; Potret Tionghoa Singkawang. Jakarta: RAH and Partners Law Firm.

Dawis, Aimee. 2010. Orang Indonesia Tionghoa mencari identitas. Translated by Maria Elvire Sundah. Jakarta: Gramedia Pustaka Utama. [Original title The Chinese of Indonesia and their search for identity; The relationship between collective memory and the media; Amherst: Cambria Press, 2009.]

Erniwati. 2007. Asap hio di ranah Minang; Komunitas Tionghoa di Sumatera Barat. Yogyakarta: Ombak, Jakarta: Yayasan NABIL.

Gunawan, Hendri Dwikoratno. 2013. Yok Tjae E Chung Hwa; Menelusuri jejakjejak komunitas Tionghoa di Manado. Yogyakarta: Kanisius.

Hoon, Chang-Yau. 2012. Identitas Tionghoa; pasca-Suharto; Budaya, politik dan media. Jakarta: Yayasan NABIL, LP3ES.

Mahfud, Choirul. 2013. Manifesto politik Tionghoa di Indonesia. Yogyakarta: Pustaka Pelajar. 
Purdey, Jemma. 2006. Anti-Chinese violence in Indonesia, 1996-1999. Singapore: Asian Studies Association of Australia, in association with Singapore University Press.

Sai, Siew Min and Hoon Chang Yau (eds). 2013. Chinese Indonesians reassessed. London: Routledge.

Salmon, Claudine. 2010. Sastra Indonesia awal; Kontribusi orang Tionghoa. Translated by Ida Sundari Husen et al. Jakarta: Kepustakaan Populer Gramedia.

Setyautama, Drs. Sam. 2008. Tokoh-tokoh Etnis Tionghoa di Indonesia. Jakarta: Kepustakaan Populer Gramedia, Chen Xingchu Foundation.

Winarno, Bondan. 2004. "Etnis Tionghoa keluar dari lemari", Tempo, Majalah Berita Mingguan 17 August (special edition): 84-85.

MAGAZINES

Sinar Harapan 12 October 2004.

Tempo, Majalah Berita Mingguan 17 August 2004 (special edition).

Tempo, Majalah Berita Mingguan 31 August 2015.

The Jakarta Post, Weekender Magazine February 2008.

The Straits Times 5 August 1998. 